\title{
Bipedal locomotion in Tropidurus torquatus (Wied, 1820) and Liolaemus lutzae Mertens, 1938
}

\author{
Rocha-Barbosa, O.*, Loguercio, MFC., Velloso, ALR. and Bonates, ACC. \\ Departamento de Zoologia, Instituto de Biologia Roberto Alcantara Gomes, \\ Universidade do Estado do Rio de Janeiro - UERJ, \\ Rua São Francisco Xavier, 524, Maracanã, CEP 20550-013, Rio de Janeiro, RJ, Brazil \\ *e-mail: obarbosa@uerj.br \\ Received December 12, 2006 - Acceped March 25, 2007 - Distributed August 31, 2008
}

(With 2 figures)

\begin{abstract}
Bipedalism has evolved on numerous occasions in phylogenetically diverse lizard families. In this paper we describe, for the first time, bipedal locomotion on South American lizards, the sand-dweller Liolaemus lutzae and the generalist Tropidurus torquatus. The lizards were videotaped running on a racetrack and the sequences were analyzed frame by frame. The body posture, as a whole, diverged a lot during bipedal locomotion between the two species, even though there was no difference regarding their sprint performance. The locomotor behavior of $L$. lutzae is, in general, more similar to the one observed on other sand-dweller lizards. Certain particularities are common, such as the digitigrade posture at footfall and throughout stance, trunk angles; and tail posture. In contrast, T. torquatus exhibited high trunk angles and dragged its tail, in a posture compared to basilisks. This body posture could be related to certain characteristics and obstacles of a microhabitat such as the one around lakes and streams (basilisks) and the one with compact shrubby vegetation (T. torquatus).
\end{abstract}

Keywords: bipedality, kinematics, locomotion, Tropidurus, Liolaemus.

Bipedalismo em Tropidurus torquatus (Wied, 1820) e Liolaemus lutzae Mertens, 1938

\section{Resumo}

O bipedalismo apareceu em inúmeras ocasiões em famílias de lagartos filogeneticamente diversas. Neste trabalho, descrevemos, pela primeira vez, locomoção bipedal em lagartos sul-americanos, o lagarto de hábito terrestre Liolaemus lutzae e o generalista Tropidurus torquatus. Os lagartos foram filmados correndo em uma pista de corrida e as seqüências foram analisadas quadro a quadro. A postura corporal, como um todo, divergiu bastante durante a locomoção bipedal das duas espécies, mesmo quando não houve diferença significativa em relação ao desempenho locomotor. O comportamento locomotor de L. lutzae é, em geral, similar ao observado em outros lagartos especialistas em solos arenosos. Certas particularidades são comuns, como a postura digitígrada no momento de apoio e durante a fase de apoio; ângulos do corpo e postura da cauda. Em contraste, T. torquatus exibiu altos ângulos corporais e arrastava sua cauda, numa postura comparada à dos lagartos basiliscos. Este tipo de postura corporal pode estar relacionado com certas características e obstáculos de um microhabitat como ao redor de rios e riachos (basiliscos) e uma vegetação de arbustos compacta (T. torquatus).

Palavras-chave: bipedalismo, cinemática, locomoção, Tropidurus, Liolaemus.

\section{Introduction}

Among small terrestrial vertebrates, lizards have served as a model for testing locomotor performance (Garland and Losos, 1994), especially because of their great diversity in morphology, behavior, habitat utilization and life-history strategies (Huey et al., 1983). To justify this ecological variety, lizards exhibit different gaits, from quadrupedal and bipedal species (e.g. Irschick and Jayne, 1999), to terrestrial and arboreal specialists (e.g. Mori and Hikida, 1993).

Lizard locomotion is strongly influenced by body shape and length, as well as by several habitat attributes such as temperature, substrate, inclination and perch diameters (Carothers, 1986; Losos and Sinervo, 1989; Losos and Irschick, 1996; Irschick and Jayne, 1998). Nevertheless, in general there are four forms of locomotion in lizards: a quadrupedal walk at low speeds; a quadrupedal fast gait, also called reptilian trot; a diagonal run at high speeds; and the bipedal run (Croix, 1929; Howell, 1944; Snyder, 1952; Sukhanov, 1968). Several descriptions of lizard locomotor kinematics now exist (e.g. Fieler and Jayne, 1998; Irschick and Jayne, 1998; 1999; 2000; Russell and Bels, 2001), but most studies 
focus mainly on North and Central American species. Few study South American lizards (e.g. Kohlsdorf et al., 2004), particularly regarding bipedal locomotion.

Bipedalism has evolved on numerous occasions in phylogenetically diverse families such as iguanids, agamids and teiids (Irschick and Jayne, 1999; Irschick and Garland, 2001; Russell and Bels, 2001), particularly among the species that live in sandy, rocky or open environments (Snyder, 1952). As this bipedal locomotion is probably not an ancestral trait for lacertilians, parallel evolution must have occurred (Aerts et al., 2003).

For the most part, bipedality has always been related to fast locomotion and to predator avoidance. The species often shift from four to two legs at higher speeds. Snyder $(1949,1952,1962)$ argued that this gait allowed lizards to run faster because of the much larger strides they can take. However, Irschick and Jayne (1999) studied five species of lizards running at near-maximal sprinting speeds on a treadmill, and in no case was there a significant difference in maximum speed between bipedal and quadrupedal running. Snyder $(1949,1952,1962)$ also suggested that bipedal running is energetically more economical than that of quadrupedal, but similar-sized bipeds and quadrupeds seem to have similar locomotor costs (Roberts et al., 1998). Kohlsdorf and Biewener (2006), for example, observed bipedal locomotion when lizards moved over medium and high obstacles, which could be related to an enhancement in environmental perception.

Thus, why bipedality has evolved in lizards is an interesting question with many ramifications. A selective advantage of this particular gait is not directly evident. The major point is whether bipedal performance is truly adaptive in all these lizard species or whether it is just a mechanical consequence of the running movement (Irschick and Jayne, 1999; Aerts et al., 2003).

In this paper, we describe, for the first time, bipedal locomotion in South American lizards. The two species analyzed Tropidurus torquatus (Wied, 1820) and Liolaemus lutzae Mertens, 1938 live sympatrically in the Restinga da Barra de Maricá, Rio de Janeiro. They diverge significantly in microhabitat use. In Barra de Maricá, L. lutzae is restricted to the beach habitat which is an open sand dune area covered by herbaceous vegetation (Rocha, 1991), whereas T. torquatus has a larger degree of arboreality, being found on bromeliad and tree trunks (Bergallo and Rocha, 1994). Thus, we try to elucidate certain questions concerning the locomotor performance of both species: (1) Do they use bipedal gaits in high-speed performances? (2) Are there any differences between the two species regarding gait performance? (3) How do limbs and tail behave during the gait? (4) And finally, is there any relation between divergent gaits and different habitats?

\section{Material and Methods}

\subsection{Specimens}

We collected 10 adult male specimens (five $L$. lutzae - SVL: $68.2 \pm 6.8$; and five T. torquatus - SVL:
$86.8 \pm 12.2$ ) in July 2003 in the Restinga da Barra de Maricá, an area located approximately $38 \mathrm{~km}$ East of Rio de Janeiro City ( $22^{\circ} 57^{\prime} \mathrm{S}$ and $43^{\circ} 50^{\prime} \mathrm{W}$ ), in Rio de Janeiro State, southeastern Brazil. "Restinga" is the local term for sand plain vegetation; it is characterized by a flora that varies from herbaceous - at the beach area - to shrubby - on the primary and secondary dunes (Henriques et al., 1984; Silva and Somner, 1984), adapted to salty-sandy soil (Suguio and Tessler, 1984). Adhesive sheets were used as traps to capture the lizards. All specimens of Liolaemus lutzae were captured at the beach area, while T. torquatus specimens were found in the primary dune area. All animal tails were intact and showed no sign of regeneration.

Animals were kept in the laboratory for about a month, fed with tenebrio larvae and water ad libitum, and later they were reintroduced into nature. Animal Care guidelines were complied with, ensuring appropriate treatment of all animals during their time in captivity.

\subsection{Performance analysis}

During the experiments, the lizards were placed on a racetrack $(1 \mathrm{~m} \times 20 \mathrm{~cm} \times 15 \mathrm{~cm})$ with a sandpaper bottom, which provided a rough friction surface and prevented slipping. Parallel distance marks $(0.5 \mathrm{~cm}$ from each other) were set on the posterior wall and on the ground of the racetrack for reference. The lizards were then encouraged to run by tail tapping.

Individual races were captured on a fixed video camera $60 \mathrm{~Hz}$ (PANASONIC ${ }^{\circledR}$ AG-456UP) positioned laterally to the racetrack, so the race was always recorded on the right side of the animal.

The analysis was made frame by frame using the software Ariel Performance Analysis System (APAS). This system has been used by many professionals in order to better understand problems related to structure and function of living organisms (Hall, 2000). The APAS system consists of four stages: (1) first, the video sequences are captured from a VCR or camcorder directly onto the computer hard drive; (2) then, the location of each of the subject's body joints is selected and entered into the computer; (3) later, the transformation process involves transforming the relative digitized coordinates of each point in each frame to absolute image space coordinates, which is performed entirely by the computer; (4) lastly, the filter process is used to remove small random digitizing errors or "noise" from the transformed image sequence. Once an analysis sequence has been digitized, transformed and smoothed, the APAS is able to display a complete presentation of image motion data for biomechanical analysis.

The following parameters and points were analyzed: trunk inclination (reference point at the eye and the other at the hip), hip (ilium-femoral joint), knee (femoro-tibial joint) and ankle (tibio-metatarsal joint). We could not compare statistically hip, knee and ankle joints because there were not enough footfalls available for analysis. 
Body displacement and speed were calculated using as reference point the tip of the nose.

Each individual was placed on the racetrack 16 times, once in the morning and once in the afternoon, during an 8 -day experiment. The animals were encouraged to run by tail tapping. As the room was not acclimatized, the temperature during the experiment was around $27-35^{\circ}$. A race was only deemed acceptable if the lizard ran truly bipedally, such that its paws did not touch the ground throughout the stride. Races were also discarded if the animal exhibited any clear breaks in motion (e.g. like tripping).

As a result of these criteria, only $7 \%$ out of a total of 160 strides were used for data analysis: seven strides for T. torquatus and four strides for L. lutzae. The four strides from $L$. lutzae corresponded each to a different animal (one of the lizards did not display bipedalism). The seven strides from T. torquatus corresponded to all five animals. In this case, we used two strides from two of the lizards.

For the performance analysis, we calculated stride length $(\mathrm{cm})$, which corresponds to animal displacement from the moment the reference limb first touches the ground until the next time the same limb does it again - and locomotor speed $\left(\mathrm{m} . \mathrm{s}^{-1}\right)$. All variables were analyzed in relation to the locomotor cycle(s), during which each limb undergoes a periodic motion, consisting of a stance and a swing phase. The stance phase begins with the footfall and corresponds to the whole time the foot is in contact with the ground, while the swing phase begins when the foot leaves the ground and ends with the next footfall.

\section{Results}

The footfall pattern of $L$. lutzae and T. torquatus could be generalized as shown in Figures 1 and 2, respectively. Table 1 compares the sprint performance of $T$. torquatus and L. lutzae with other species from Europe, Central America and United States.
In relation to their bipedal performance, there was no significant difference between $L$. lutzae and T. torquatus (speed: $\mathrm{t}=0.973$, $\mathrm{df}=8,9, \mathrm{P}=0.356$; stride length: $\mathrm{t}=-0.424, \mathrm{df}=8,5, \mathrm{P}=0.682)($ Table 1$)$.

In all analyzed runs, T. torquatus exhibited plantigrade posture during all stance phase and footfall, digitigrady was used only at the end of the stance. In L. lutzae, the foot posture remained digitigrade both at footfall and throughout the stance phase.

The hips of the lizards were quite high throughout the whole stride cycle (Liolaemus: $24 \pm 1.63 \mathrm{~mm}$; Tropidurus: $46.8 \pm 10.3 \mathrm{~mm}$ ) corresponding to $30-34 \%$ SVL in L. lutzae and 29-43\% SVL in T. torquatus. Both species elongated their hind limbs by orientating them to a more parassagital position in relation to their body.

Liolaemus lutzae, at footfall, had its knee often extended $\left(145 \pm 7.07^{\circ}\right)$ sufficiently so that the ankle was anterior to the knee rather than beneath it at footfall (Figure 1a). Tropidurus torquatus displayed ankle angles $\left(67.5 \pm 10.61^{\circ}\right)$ at footfall less than $90^{\circ}$, indicating that the limb was flexed upon contact with the ground (Figure 2a). Its knee at footfall was $105.5 \pm 12.02^{\circ}$.

Although body angle remained relatively constant during locomotion for both species, T. torquatus ran with more erect postures than did L. lutzae. The latter exhibited trunk angles around $9^{\circ}$, maintaining its body in an almost horizontal position, whereas T. torquatus displayed a more oblique body position, about $24^{\circ}$ (Table 1 ).

Knee height was very different between the species, especially during the swing phase. While the knee of $T$. torquatus achieved very high values (53.15 $\pm 14.98 \mathrm{~mm}$, i.e., $40 \pm 11 \% \mathrm{SVL}$ ) (Figure 2d), that of L. lutzae did not ( $23.18 \pm 3.86 \mathrm{~mm}$, i.e., $30 \pm 5 \%$ SVL) (Figure 1d). Liolaemus lutzae often displayed an "aerial phase", in which neither foot is touching the ground (Figure 1d).

Regarding the forelimb motion during the locomotor cycle, on L. lutzae, the left arm swings in phase with the right foot, in a diagonal limb motion; while on

Table 1. Performance variables during bipedal locomotion of some lizards. N, corresponds to the number of locomotor cycles analyzed.

\begin{tabular}{|c|c|c|c|c|c|}
\hline Species & $\mathbf{N}$ & $\begin{array}{l}\text { Speed } \\
\left(\mathrm{m} . \mathrm{s}^{-1}\right)\end{array}$ & $\begin{array}{l}\text { Stride length } \\
(\mathrm{cm})\end{array}$ & $\begin{array}{c}\text { Trunk angle } \\
\text { (degrees) }\end{array}$ & References \\
\hline Tropidurus torquatus & 7 & $1.5 \pm 0.2$ & $14.14 \pm 2.12$ & $24 \pm 1$ & This study \\
\hline Liolaemus lutzae & 4 & $1.6 \pm 0.1$ & $13.62 \pm 0.8$ & $9 \pm 1$ & This study \\
\hline Calissaurus draconoides & 14 & $4.5 \pm 0.1$ & $31.8 \pm 1.0$ & $8 \pm 1$ & Irschick and Jayne, 1999 \\
\hline Uma scoparia & 4 & $3.8 \pm 0.1$ & $26.9 \pm 0.7$ & $15 \pm 1$ & Irschick and Jayne, 1999 \\
\hline Dipsosaurus dorsalis & 15 & $3.7 \pm 0.1$ & $31.0 \pm 0.9$ & $11 \pm 1$ & Irschick and Jayne, 1999 \\
\hline Cnemidophorus tigris & 6 & $3.2 \pm 0.1$ & $31.1 \pm 1.2$ & $15 \pm 1$ & Irschick and Jayne, 1999 \\
\hline $\begin{array}{l}\text { Basiliscus plumifrons } \\
\text { (water-running) }\end{array}$ & 11 & $1.3 \pm 0.1$ & - & $52 \pm 2$ & Hsieh, 2003 \\
\hline $\begin{array}{l}\text { Basiliscus } \\
\text { (terrestrial running) }\end{array}$ & $?$ & $2.5-3.0$ & - & $8-15$ & $\begin{array}{l}\text { Snyder, 1949; } \\
\text { Snyder, 1952; }\end{array}$ \\
\hline
\end{tabular}




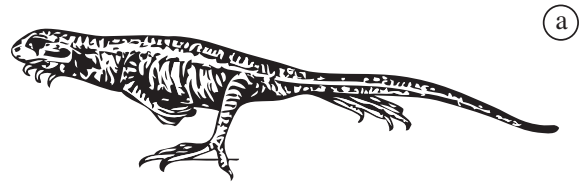

(b)

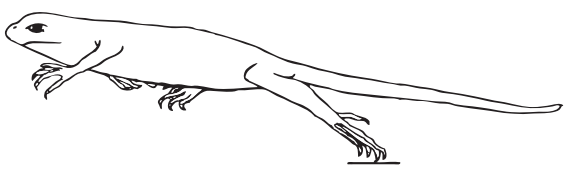

(c)

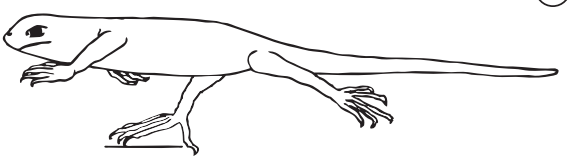

(d)

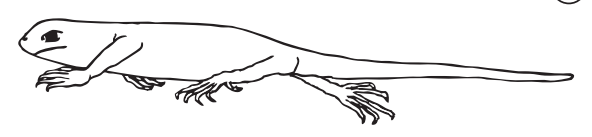

(e)

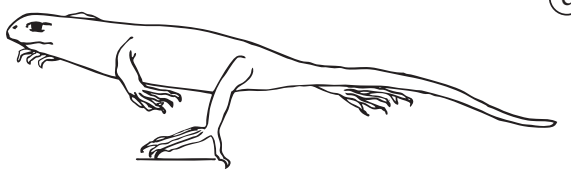

Figure 1. Left lateral view of bipedal stride at a, e) footfall, b) end of the stance phase and c, d) swing phase for Liolaemus lutzae. Snout-vent length $=75 \mathrm{~mm}$.

T. torquatus the forelimbs were in phase with the hind limbs, i.e., the left arm swings in phase with left foot and the right arm, with the right foot.

Tail orientation diverged a little between both species: in L. lutzae, it remained in a horizontal position; and in T. torquatus, the tail tilts downward in relation to trunk angle.

\section{Discussion}

Liolaemus lutzae and Tropidurus torquatus ran surprisingly slowly in comparison with other terrestrial lizards, achieving sprint velocities more similar to the ones of the water-running Basiliscus (Table 1). This difference could be related to the different methodologies used: treadmill (Irschick and Jayne, 1999) vs. track (Hsieh, 2003; present study).

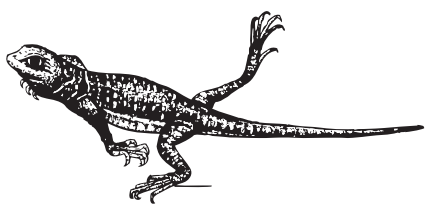

(a)

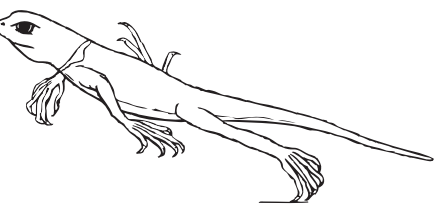

(b)

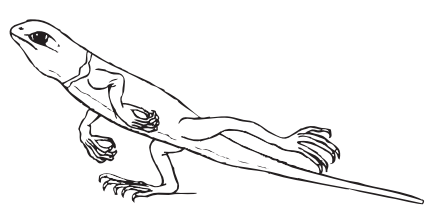

(c)

(d)

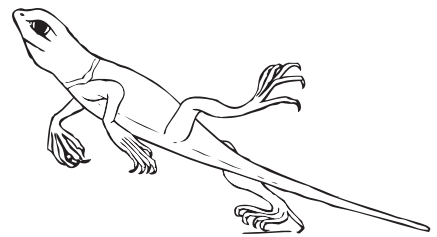

(e)

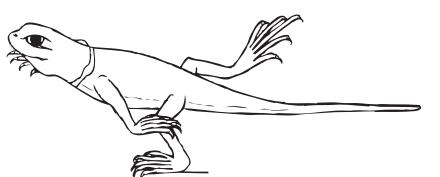

Figure 2. Right lateral view of bipedal stride at a, e) footfall, b) end of the stance phase and c, d) swing phase for Tropidurus torquatus. Snout-vent length $=130 \mathrm{~mm}$.

The treadmill enables certain variations that elicit the fastest possible speed (maximal speed). Nonetheless, recent studies comparing laboratory and field results show that, sometimes, lizards have relatively low speeds in the field when compared to their maximal sprinting capacities found in the laboratory (Irschick and Jayne, 1998). On the racetrack, we are not able to control the speed, but all runs represent the lizards' preferred sprint speed (Hsieh, 2003). Perhaps the performance on the racetrack is more similar to the one in the field, as the lizard has the same escape behavior it would exhibit when facing a predator in its real environment. But this hypothesis still needs corroboration in future studies.

The body posture, as a whole, diverged a lot during bipedal locomotion between the two species we ana- 
lyzed. In general, the forelimbs "windmill" during a run, but to different extents. While in L. lutzae, the left arm swings in phase with the right foot, in a diagonal limb motion, in T. torquatus, the forelimbs were in phase with the hind limbs.

Hsieh (2003) observed a certain variation in the forearm motion during basilisks' water running, i.e. the lizards would extend their arms forward with minimal shoulder rotation; their arm movements would match with the contralateral leg; or even, they would nearly match the motions with the hind limb on the same side. Overall, the swinging of the forelimbs seems to counteract torques in the body during a stride, as have been previously reported in humans (Li et al., 2001). As during each locomotor cycle the center of gravity changes, some compensatory adjustments must be continuously made. The "windmill" of the forelimbs functions thus as a small amount of compensation for this constant shift of the center of gravity (Russel and Bels, 2001).

The function of the tail in lizard locomotion has been overlooked in several previous studies. Nevertheless, during terrestrial locomotion, it has an important role, acting to counterbalance the elevated trunk of a biped (Snyder, 1962; Alexander, 1984) and to regulate stride frequency (Hamley, 1990). Tail orientation may improve limb muscle function in tetrapods for which hind limb retractor muscles attach to the tail (Willey et al., 2004). Dorsiflexion of the tail in lizards, such as in Calissaurus draconoides and Uma scoparia, may stretch the caudofemoralis muscle, thereby enhancing the muscle's ability to generate propulsive force (Irschick and Jayne, 1999). Even large reptiles, such as Crocodylus, also elevate their tail during quick galloping bouts, presumably to improve their running mechanics (Renous et al., 2002). Basilisks, on the other hand, drag their tails behind them while running through water. The mass of the fluid above the tail and the skin frictional drag from the fluid surrounding the tail seem to aid in keeping basilisks in an upright posture (Hsieh, 2003).

Tail posture in relation to the ground also diverged between L. lutzae and T. torquatus: in the first, it remained in a horizontal position; and in the latter, the tail tilts downward in relation to trunk angle. The passively generated torque of the tail about the hip joint would be maximized when the tail is held horizontally (Irschick and Jayne, 1999), as in L. lutzae. This posture thus positions the center of mass of the tail as far as possible from the center of the hip. Tropidurus tail posture is more similar to that of basilisks (Snyder, 1949; Hsieh, 2003), which may produce some thrust in the terrestrial run. Yet still there seems to be no correlation between tail angles and bipedal locomotion (Irschick and Jayne, 1999).

Inclination of body in relation to the substrate seems to change with speed in some iguanids, agamids and teiids (Barbour, 1926; Snyder, 1952; Urban, 1965). The faster the lizard, the greater is the angle. However, Irschick and Jayne (1999) observed no correlation between trunk angles and bipedal running in Callisaurus draconoides. The lizard L. lutzae kept its body in an almost horizontal position, with trunk angles similar to C. draconoides, even though its bipedal speed was considered high (Table 1). On the other hand, T. torquatus exhibited considerably higher trunk angles (Table 1), as in many previous values on bipedal locomotion (see Urban, 1965 for a review).

The horizontal position of the body and tail in L. lutzae could also be interpreted as a way to minimize effort in digging. The digging method of this sand-dweller lizard is called, according to Hildebrand (1995), cover-up digging, in which the lizard covers itself with sand to escape from predators. This lizard commonly runs away from predators, sometimes using bipedal running, but always at high speeds, hiding very fast in the sand (Rocha-Barbosa, personal communication). Keeping its body close to the substratum could reduce effort during digging, with a smaller variation in angle at the moment of diving through sand. Nonetheless, detailed studies are needed to clarify a real correlation between these two variables.

Footfall patterns are commonly known to change with increasing speed. Lizards running at high speeds frequently have digitigrade foot posture at footfall and throughout stance (Fieler and Jayne, 1998; Irschick and Jayne, 1999). In the sand-dweller L. lutzae, the same pattern was observed. On the other hand, T. torquatus exhibited plantigrady throughout most of the stance and footfall, a similar performance to Phrynosoma platyrhinos (Irschick and Jayne, 1999). Reilly and Delancey (1997) also reported that, in Sceloporus clarkii, the feet struck the substratum either heel-first or in a plantigrade fashion during a walking trot.

The link between digitigrade posture and cursoriality often occurs in other vertebrates, such as mammals and even birds (Alexander, 1984). Even though lizards with digitigrady seem to achieve higher speeds than the ones with plantigrade posture during bipedal locomotion (Reilly and Delancey, 1997; Irschick and Jayne, 1999), it seems there is no correlation between foot posture and lizard bipedality. Variance observed so far may be due to differences in experimental set up or it even may reflect differences in limb design and mechanics between lineages (Russel and Bels, 2001).

Urban (1965) reported that the hind limbs are more fully straightened in bipeds than in quadrupeds and this was also noted by Irschick and Jayne (1999). In fast moving forms, the femur moves from a horizontal to a more vertical position, bringing the axis of the femur to a more parassagital plane. In the desert iguana, Dipsosaurus dorsalis, for example, the height of the hip at the time of footfall increases significantly with increased speed (Fieler and Jayne, 1998). Our data also seem to corroborate this idea, as both $T$. torquatus and L. lutzae kept their hips quite high throughout the whole bipedal stride cycle. Yet, this was not the case with relatively slowly moving species (Reilly and Delancey, 1997). Hip height thus can be related to faster speeds, and consequently, to 
bipedal gaits, particularly enhancing the clearance of the forelimbs relative to the locomotor surface (Irschick and Jayne, 1999).

Extension of the knee beyond $90^{\circ}$ at footfall also contributes to increase hip height (Irschick and Jayne, 1999). This was observed in L. lutzae, but not in T. torquatus that had a more crouched position at footfall.

In general, comparing L. lutzae and T. torquatus during bipedality and other lizards such as Basiliscus, Anolis, Varanus, Uranoscodon, Dipsosaurus and Callisaurus (see Barbour, 1943; Snyder, 1967; Howland et al., 1990; Irschick and Jayne, 1999; Hsieh, 2003) it is clear that each one of these lizards uses different strategies during their bipedal running. As suggested by Irschick and Jayne (1999), this could be the result of independent specializations in these species, which display different degrees of efficiency in the execution of these particular movements. Therefore, bipedalism involves a complexity of locomotor behaviors that could be related to the lizards' environment instead of their phylogeny.

The common elements of habitat associations with saurian bipedal locomotion were first considered by Snyder (1952), who divided bipeds into two groups: primarily terrestrial species living in open, sandy or rocky areas; and lizards living in brushy or forested areas that may be classed as arboreal or semi-arboreal. Both L. lutzae and T. torquatus could be classified into the first group. Yet, even though there was no difference regarding their locomotor performance, they exhibited divergent patterns of bipedal running that could be related to the different ways they use their microhabitat, as one is a sand-dweller lizard and the other is more generalist.

The locomotor behavior of L. lutzae is, in general, more similar to the one observed in the lizards described by Irschick and Jayne (1999), particularly, Dipsosaurus dorsalis and Callisaurus draconoides. Certain particularities are common, such as the digitigrade posture at footfall and throughout stance; trunk angles; and tail posture. As these lizards are all ground-dwellers that live in open environments, this locomotor behavior may be related to a common escape behavior.

In contrast, $T$. torquatus uses its microhabitat in a more vertical way, being found on rocks, bromeliad and tree trunks. Its high trunk angles and dragged tail can be compared to a basilisk running posture (Snyder, 1949; Hsieh, 2003). This body posture could be related to certain characteristics and obstacles of a microhabitat such as the one around lakes and streams (basilisks) and the one with compact shrubby vegetation (T. torquatus).

The fact that the real advantages of bipedalism are still in debate increases the importance of any kinematic or descriptive data on the subject. Earlier claims that bipedal locomotion maximize speed (Snyder, 1952) were questioned recently by Irschick and Jayne (1999) who found no arguments for a speed advantage of bipedal performance. Aerts et al. (2003) suggest that small lizards engage passively in bipedal running bouts, as a consequence of fast accelerations. The bipedal locomotion of T. torquatus and L. lutzae occurs at relatively highspeeds, but further studies comparing quadrupedal gaits are required to test this hypothesis.

Overall, even though both lizards run bipedally at high-speed performances, we did not find any difference regarding gait performance. What we suggest is that certain bipedal parameters, especially body posture, could be related to microhabitat adaptation. The divergent tail posture and body inclination between L. lutzae and T. torquatus during these high-speed gaits can be associated to the different habitats these two lizards occupy. Although we were not able to elucidate questions regarding the origin of bipedality in lizards, this study substantially contributes to the field of biomechanics by establishing for the first time a parallel between bipedalism of the Central American, European and North American species and those from Brazil.

Acknowledgements - Programa Prociência/UERJ, FAPERJ Process number E-26/170.654/2004, PPGB-UERJ for financial support. O.R-B: CRBIO 02085. We would like to thank two anonymous referees for the ideas and suggestions that helped to improve this paper.

\section{References}

AERTS, P., VAN DAMME, R., D'AOUT, K. and VAN HOOYDONCK, B., 2003. Bipedalism in lizards: whole-body modelling reveals a possible spandrel. Phil. Trans. R. Soc. Lond. $B$, vol. 358 , no. 1437 , p. $1525-1533$.

ALEXANDER, RM., 1984. The Gaits of Bipedal and Quadrupedal Animals. Int. J. Rob. Res., vol. 3, no. 2, p. 49-59.

BARBOUR, T., 1926. Reptiles and Amphibians: Their Habits and Adaptations. Boston: Houghton and Mifflin.

-, 1943. Defense Posture of Varanus Gouldii. Copeia, vol. 1943, no. 1, p. $56-57$.

BERGALLO, H. and ROCHA, CFD., 1994. Spatial and trophic niche differentiationin two sympatric lizards (Tropidurus torquatus and Cnemidophorus ocellifer) with different foraging tactics. Aust. J. Ecol., vol. 19, no. 1, p. 72-75.

CAROTHERS, JH., 1986. An Experimental Confirmation of Morphological Adaptation: Toe Fringes in the Sand-Dwelling Lizard Uma Scoparia. Evolution, vol. 40, no. 4, p. 871-874.

CROIX, PM., 1929. Filogenia De Las Locomociones Cuadrupedal Y Bipedal En Los Vertebrados Y Evolución De La Forma Consecutiva De La Locomoción. Ann. Soc. Cient. Argentina, vol. 108, p. 383-406.

FIELER, CL. and JAYNE, BC., 1998. Effects of Speed on the Hindlimb Kinematics of the Lizard Dipsosaurus Dorsalis. J. Experim. Biol., vol. 201, no. 4, p. 609-622.

GARLAND, TJ. and LOSOS, JB., 1994. Ecological Morphology of Locomotor Performance. In WAINWRIGHT, PC. and REILLY, SM. (Ed.). Ecological Morphology: Integrative Organismal Biology. Chicago: University of Chicago Press. p. 240-302.

HALL, SJ. 2000. Biomecânica Básica. 3 ed. São Paulo: Guanabara Koogan. 417 p. 
HAMLEY, T., 1990. Functions of the tail in bipedal locomotion of lizards, dinosaurs and pterosaurs. Mem. Queensl. Mus., vol. 28 , no. 1 , p. $153-158$.

HENRIQUES, RPB., MEIRELES, ML. and HAY, JD., 1984. Ordenação E Distribuição De Espécies Das Comunidades Vegetais Na Praia Da Restinga Da Barra De Maricá, Rj. Rev. Bras. Bot., vol. 7, p. 27-36.

HILDEBRAND, M., 1995. Análise Da Estrutura Dos Vertebrados. São Paulo: Atheneu Editora.

HOWELL, AB., 1944. Speed in Animals. Chicago: University of Chicago Press.

HOWLAND, JM., VITT, LJ. and LOPEZ, PT., 1990. Life on the Edge - the Ecology and Life-History of the Tropidurine Iguanid Lizard Uranoscodon-Superciliosum. Can. J. Zool., vol. 68 , no. 7 , p. $1366-1373$.

HSIEH, ST., 2003. Three-Dimensional Hindlimb Kinematics of Water Running in the Plumed Basilisk Lizard (Basiliscus Plumifrons). J. Exp. Biol., vol. 206, no. 23, p. 4363-4377.

HUEY, RB., PIANKA, E. and SCHOENER, TW., 1983. Lizard Ecology: Studies of a Model Organism. Cambridge: Harvard Univeristy Press.

IRSCHICK, DJ. and JAYNE, BC., 1998. Effects of Incline on Speed, Acceleration, Body Posture and Hind Limb Kinematics in Two Species of Lizard, Callisaurus Draconoides and Uma Scoparia. J. Exp. Biol., vol. 201, no. 2, p. 273-287.

-, 1999. Comparative Three-Dimensional Kinematics of the Hindlimb for High-Speed Bipedal and Quadrupedal Locomotion of Lizards. J. Exp. Biol., vol. 202, no. 9, p. 1047-1065.

-, 2000. Size matters: Ontogenetic variation in the threedimensional kinematics of steady-speed locomotion in the lizard Dipsosaurus dorsalis. J. Exp. Biol., vol. 203, no. 14, p. 2133-2148.

IRSCHICK, DJ. and GARLAND, TJ., 2001. Integrating Function and Ecology in Studies of Adaptation: Investigations of Locomotor Capacity as a Model System. Ann. Rev. Ecolog. Syst., vol. 32, p. 367-396.

KOHLSDORF, T. and BIEWENER, AA. 2006. Negotiating obstacles: running kinematics of the lizard Sceloporus malachiticus. J. Zool., vol. 270, no. 2, p. 359-371.

KOHLSDORF, T., JAMES, RS., CARVALHO, JE., WILSON, RS., DAL PAI-SILVA, M. and NAVAS, CA. 2004. Locomotor performance of closely related Tropidurus species: relationships with physiological parameters and ecological divergence. $J$. Exp. Biol., vol. 207, no. 7, p. 1183-1192.

LI, Y., WANG, W., CROMPTON, RH. and GUNTHER, MM., 2001. Free vertical moments and transverse forces in human walking and their role in relation to arm-swing. J. Exp. Biol., vol. 204 , no. 1 , p. 47-58.

LOSOS, JB. and SINERVO, B., 1989. The Effects of Morphology and Perch Diameter on Sprint Performance of Anolis Lizards. J. Exp. Biol., vol. 145, no. 1, p. 23-30.
LOSOS, JB. and IRSCHICK, DJ., 1996. The Effect of Perch Diameter on Escape Behaviour of Anolis Lizards: Laboratory Predictions and Field Tests. Anim. Behav, vol. 51, no. 3, p. 593-602.

MORI, A. and HIKIDA. T., 1993. Natural History Observations of Flying Lizard, Draco Volans Sumatranus (Agamidae, Squamata) from Sarawak, Malaysia. Raff. Bull. Zool., vol. 41, p. 83-94.

REILLY, SM. and DELANCEY, ML., 1997. Sprawling Locomotion in the Lizard Sceloporus Clarkii: The Effects of Speed on Gait, Hindlimb Kinematics, and Axial Bending During Walking. J. Zool., vol. 243, no. 4, p. 417-433.

RENOUS, S., GASC, JP., BELS, VL. and WICKER, R., 2002. Asymmetrical gaits of juvenile Crocodylus johnstoni, galloping Australian crocodiles. J. Zool. vol. 256, no. 3, p. 311-325.

ROBERTS, TJ., KRAM, R., WEYAND, PG. and TAYLOR, CR., 1998. Energetics of bipedal running I. Metabolic cost of generating force. J. Exp. Biol., vol. 201, no. 19, p. 2745-2751.

ROCHA, CFD., 1991. Composição do habitat e uso do espaço por Liolaemus lutzae (Sauria: Iguanidae) em uma área de Restinga. Rev. Bras. Biol. $=$ Braz. J. Biol., vol. 51, no. 4, p. 839-845.

RUSSELL, AP. and BELS, VL., 2001. Biomechanics and kinematics of limb-based locomotion in lizards: Review, Synthesis and Prospectus. Comp. Biochem. Physiol. A, vol. 131, no. 1 , p. 89-112.

SILVA, JG. and SOMNER, GV., 1984. A Vegetação Da Restinga Na Barra De Maricá, Rj. In LACERDA, LD. (Ed.). Restingas: Origem, Estrutura E Processo. Niterói: CEUFF. p. 217-225.

SNYDER, RC., 1949. Bipedal locomotion of the lizard Basiliscus basiliscus. Copeia, vol. 1949, no. 2, p. 129-137.

-, 1952. Quadrupedal and Bipedal Locomotion of Lizards. Copeia, vol. 1952, no. 2, p. 64-70.

-, 1962. Adaptations for bipedal locomotion of lizards. Am. Zool., vol. 2, no. 2, p. 191-203.

-, 1967. Adaptative Values of Bipedalism. Amer. J. Phys. Anthrop., vol. 26, no. 2, p. 131-134.

SUGUIO, K. and TESSLER, MG., 1984. Planícies De Cordões Litorâneos Do Brasil: Origem E Nomenclatura. In LACERDA, LD. (Ed.). Restingas: Origem, Estrutura E Processo. Niterói: CEUFF. p. 195-216.

SUKHANOV, VB., 1968. General System of Symmetrical Locomotion of Terrestrial Vertebrates and Some Features of Movement of Lower Tetrapods. New Delhi: Amerind Publications.

URBAN, EK., 1965. Quantitative Study of Locomotion in Teiid Lizards. Anim. Behav., vol. 13, no. 4, p. 513-529.

WILLEY, JS., BIKNEVICIUS, AR., REILLY, SM. and EARLS, KD., 2004. The tale of the tail: limb function and locomotor mechanics in Alligator mississippiensis. J. Exp. Biol., vol. 207, no. 3 , p. 553-563. 